\title{
Analysis Water Balance of Lake Toba as Source an Integrated Water Regional Management (IWRM) North Sumatera
}

\author{
Wesli \\ Department of Civil Engineering, Universitas Malikussaleh, Province of Aceh, Indonesia \\ Cot Tengku Nie, Kecamatan Muara Batu, Kabupaten Aceh Utara, Aceh, Indonesia \\ Telephone +62645-41373, Fax +6245-44450 \\ Email: wesli@unimal.ac.id
}

\begin{abstract}
The needs of raw water in Medan city increases every year in line with the population growth, whereas the quality of hygienic water in the river is insufficient. Therefore, it needs another alternative source to meet the standard quality with low cost. One of the potential sources is Lake Toba. To meet the needs North Sumatera Provincial Government intends to use Lake Toba, but it is feared that the decline of normal water level will disrupt the cruise ship, especially when anchored at the port. The Government plans a water supply system in Integrated Water Regional Management (IWRM) to be used collectively to be efficient in construction and operation. This study aims to determine the water balance of Lake Toba if used as a regional water supply and impact on normal water levels. In this paper, the normal water levels were analyzed by inflow and outflow, not based on elevations above sea level. The method of analysis is water balance analysis done in two parts, analysis of water debit requirement (output) and analysis of water supply (input) in a hydrological analysis. Comparison of the water balance is a consideration for conclusions. The results showed that the required debit was $82.37 \mathrm{~m} 3 / \mathrm{sec}$ (output discharge) while the supply of rainfall as reliable discharge was $121.79 \mathrm{~m} 3 / \mathrm{sec}$. In addition, the supply of rivers around Lake Toba contributed $87.3 \mathrm{~m} 3 / \mathrm{sec}$, resulting in total discharge to $209.09 \mathrm{~m} 3 / \mathrm{sec}$, it can be illustrated that the output discharge is less than the input discharge, so it can be concluded that Lake Toba can be used as a source of raw water and does not affect the normal water level.
\end{abstract}

Keyword - Normal Water Level, Water Balance, Integrated Water Regional Management (IWRM)

\section{INTRODUCTION}

The need for raw water of North Sumatera increases every year, especially in Medan, while the condition of raw water supply is getting worse due to pollution in the river. The problems faced by Medan today are that the field that keeps the water demand increases along with the increase of population, the result has not been able to meet the water needs of the community both in quantity and quality, the impact of regional development is the provision of the community's raw water needs [1]

The Government of North Sumatera intends to apply Integrated Water Regional Management (IWRM) to serve Medan City, Tebing Tinggi City, Pematang Siantar City, Simalungun Regency, Deli Serdang Regency and Serdang Bedagai Regency, but for Simalungun Regency, Deli Serdang and Serdang Bedagai Districts do not serve All areas cover only sub-districts which are only bypassed by pipelines. The government needs another alternative source that meets the quality standard of water and can be produced at low cost. One of the potential sources is Lake Toba which is located very far from the city of Medan about $175 \mathrm{~km}$. To meet the needs until 2032, the North Sumatera Provincial Government intends to use Lake Toba, but it is feared that the decline of normal water level will disrupt the cruise ship, especially when anchored at the port, because from 1984 to 1987 there was a drastic drop in water levels in Lake Toba that use water for power generation was released from the lake at a higher rate than net inflows into the lake [2]. In addition, Lake Toba is far from the city of Medan, the estimated cost of infrastructure will be expensive.

In 2014, the population in Medan was 2,191,140 people, in Tebing Tinggi 154,804 people, Pematang Siantar 245,104 people, Simalungun 844,033 people, Deli Serdang 1,984,598 and Serdang Bedagai 606,367 people. By 2015, the population in Medan increased to 2,210,624 people, Tebing Tinggi 156,815 people, Pematang Siantar 247,411 people, Simalungun 849,405 people, Deli Serdang 2,029,308 and Serdang Bedagai 608,691 people [3].

The Government plans a water supply system in Integrated Water Regional Management (IWRM) to be used collectively to be efficient in construction and operation. Integrated Area Water Management will serve the area along the pipe crossings. The service area is divided into two channels, namely, Medan-Deli Serdang channel 1 and Tebing Tinggi-Pematang Siantar-Simalungun-Serdang-Bedagai channel 2. 
This study aims to determine water balance of Lake Toba as a source an Integrated Water Regional Management (IWRM) and impact on normal water levels. In this study, normal water levels were analyzed by inflow and outflow, not based on elevations above sea level. If the outflow is greater than the release of the inflow, it will decline the normal water level.

\section{MeTHOdOLOGY}

The research method used in this research was water balance analysis done in two parts that are analysis of water demand (output) and analysis of water supply (input) through hydrological analysis. Comparison of water balance was a consideration for a conclusion.

\section{A. The Analysis of Discharge Water Demand (Output)}

The analysis of water demand (output) is based on a number of populations forecasting up to 2032. Population forecasting used the geometric method:

$$
P_{n}=P_{o}(1+r)^{n}
$$

Where "Pn" is the total of a population in the year to "n", while "Po" is the number of the base year population and " $r$ " is the average population growth and also " $n$ " is the number of years.

The official population forecasting for Indonesia shows that considerable population growth will take place over the next 25 years, though the rate of increase will be slowing. As this brief note has stressed, the growth of population in Indonesia should be manageable, and the changes in age structure will in many ways be favorable for more rapid economic development, though much will depend on the quality of Indonesia's economic and social planning [4].

The water need is determined based on the population, the level of service and the standard of water use which consists of three categories: domestic demand, non-domestic needs, and water loss. Population growth and population existing are shown in Table I.

TABLE I. Population Existing and Population Growth

\begin{tabular}{|l|c|c|c|}
\hline \multicolumn{1}{|c|}{ District } & $\mathbf{2 0 1 4}$ & $\mathbf{2 0 1 5}$ & Population Growth (\%) \\
\hline Medan & $2,191,140$ & $2,210,624$ & 0.009 \\
\hline Tebing Tinggi & 154,804 & 156,815 & 0.013 \\
\hline Pematang Siantar & 245,104 & 247,411 & 0.009 \\
\hline Simalungun & 844,033 & 849,405 & 0.006 \\
\hline Deli Serdang & $1,984,598$ & $2,029,308$ & 0.023 \\
\hline Serdang Bedagai & 606,367 & 608,691 & 0.004 \\
\hline
\end{tabular}

Domestic water needs use Connection House $(\mathrm{CH})$ and Public Hydrant $(\mathrm{PH})$ ratio 80:20, and this will increase to 90:10 where $1 \mathrm{CH}$ serves 5 people and $1 \mathrm{PH}$ serves 100 people. Table 2 shows the average needs of household drinking water.

TABLE II. The average of household water consumption

\begin{tabular}{|l|c|c|}
\hline \multicolumn{1}{|c|}{ Region } & Total Population & Water Consumption (Liters/people/day) \\
\hline City & $>1.000 .000$ & 240 \\
\hline Metropolitan & $500.000-1.000 .000$ & 190 \\
\hline Big City & $100.000-500.000$ & 150 \\
\hline Medium city & $10.000-100.000$ & 110 \\
\hline Town Village & $3.000-10.000$ & 90 \\
\hline
\end{tabular}

Non-domestic needs, urban survey categories I, II, and III were determined by municipalities related to city master plans. For cities, category IV non-households required $20 \%$ of household needs, while the category of city $\mathrm{V}$ was $10 \%$ of household needs. Based on the criteria of integrated water supply system planning, the losses due to the piping system were $20 \%$, in accordance with the provisions of drinking water standards and services for a maximum daily factor of 1.15 and a maximum hours factor of 1.75 based on estimates water needs was tailored to the treatment system and the level planned service level [5].

\section{B. The Analysis of Water Supply (Input) Through the Hydrological Analysis}

Water availability is determined by Hydrological Analysis using rainfall data in watersheds and lake discharge to the river. The rainfall data used in the hydrological analysis is the monthly rainfall area Situnggaling, Sitinjo (Dairi around), Tanjung Gorbus, Pangururan (around Samosir), Dolok Bun, Laguboti 
(Toba Samosir around) and Lumban Julu around. The rainfall data used in this research is 15 years from 1993 to 2007.

Analysis of rainfall data can be done by various methods, such as the Average Algebra Method, Isohyet Method, and Thiessen Method [6]. In this paper the maximum daily rainfall data is Approach with the Average Algebra Method using the equation:

$$
R=\frac{1}{n}\left(R_{1}+R_{2}+\ldots \ldots \ldots+R_{n}\right)
$$

Where " $R$ " is the rainfall area, " $n$ " is the number of points or the observation post and " $R_{1}, R_{2}, \ldots R_{n}$ " is rainfall at each point of observation.

\section{The Rainfall Data Test}

The average rainfall is based on rainfall data from 4 stations and for this analysis the minimum water needs are calculated. If rainfall has been met, the minimum water needs are met. Rainfall data for each data consistency is tested by Rescaled Adjusted Partial Sum (RAPS) method. Test data consistency with cumulative deviation test [7]. For test data is determined as follows:

$$
\begin{aligned}
& S_{K} *=\sum_{i=1}^{k}\left(Y_{i}-\bar{Y}\right) \\
& D_{y}{ }^{2}=\frac{\left(S_{K}\right)^{2}}{n} \\
& D_{y}=\frac{\sum D_{y}^{2}}{n} \\
& S_{K} * *=\frac{S_{K} *}{D_{y}}
\end{aligned}
$$

Statistical value $\mathrm{Q}$ and $\mathrm{R}$ are:

$$
\begin{aligned}
& Q=\operatorname{Maks}\left|S_{K} * *\right| \text { untuk } 0 \leq k \leq n \\
& R=\operatorname{Maks}\left|S_{K} * *\right|-\operatorname{Min}\left|S_{K} * *\right|
\end{aligned}
$$

Based on the above statistical values can be determined the value of $\mathrm{Q} / \mathrm{n}^{(0.5)}$ and $\mathrm{R} / \mathrm{n}^{(0.5)}$, the results are compared with the value of $\mathrm{Q} / \mathrm{n}^{(0.5)}$ and $\mathrm{R} / \mathrm{N}^{(0.5)}$ required (value Table III). The value is smaller than the consistent data.

TABLE III. Table Values for $\mathrm{Q} / \mathrm{n}^{(0,5)}$ and $\mathrm{R} / \mathrm{n}^{(0,5)}$

\begin{tabular}{|c|c|c|c|c|c|c|}
\hline \multirow{2}{*}{$\mathrm{n}$} & \multicolumn{3}{|c|}{$\mathrm{Q} / \mathrm{n}^{0,5}$} & \multicolumn{3}{c|}{$\mathrm{R} / \mathrm{n}^{0,5}$} \\
\cline { 2 - 7 } & $90 \%$ & $95 \%$ & $99 \%$ & $90 \%$ & $95 \%$ & $99 \%$ \\
\hline 10 & 1,05 & 1,14 & 1,29 & 1,21 & 1,28 & 1,38 \\
\hline 20 & 1,10 & 1,22 & 1,42 & 1,34 & 1,43 & 1,60 \\
\hline 30 & 1,12 & 1,24 & 1,48 & 1,40 & 1,50 & 1,70 \\
\hline 40 & 1,14 & 1,27 & 1,52 & 1,44 & 1,55 & 1,78 \\
\hline 100 & 1,17 & 1,29 & 1,55 & 1,50 & 1,62 & 1,85 \\
\hline 200 & 1,22 & 1,36 & 1,63 & 1,62 & 1,75 & 2,00 \\
\hline
\end{tabular}

The determination of the goodness of fit test of the frequency distribution of the sample data from the probability distribution function is expected to reflect the frequency distribution of the required test parameters. For measurement, parameters can be performed by Chi-square test or Kolmogorov-Smirnov test [8]. This research used Kolmogorov-Smirnov test which is often called non-parametric test because the test did not use specific distribution function. Of these two opportunity scores determined the largest difference between observational possibilities and theoretical opportunities:

$$
D=\operatorname{maksimum}\left[P\left(Q_{\text {maks }}\right)-P^{\prime}\left(Q_{\text {maks }}\right)\right]
$$

From Table IV, the critical value of Kolmogorov-Smirnov is determined "Perform". If the "Dmax" is smaller than the "Do" distribution to determine which is acceptable, if the value "Dmax" is greater than "Perform", the distribution is unacceptable. 
TABLE IV. Critical value "Do" of Kolmogorov-Smirnov Test

\begin{tabular}{|c|c|c|c|c|}
\hline \multirow{2}{*}{$\mathbf{N}$} & \multicolumn{4}{|c|}{$\boldsymbol{0}$} \\
\cline { 2 - 5 } & $\mathbf{0 , 2 0}$ & $\mathbf{0 , 1 0}$ & $\mathbf{0 , 0 5}$ & $\mathbf{0 , 0 1}$ \\
\hline 5 & 0,45 & 0,51 & 0,56 & 0,67 \\
\hline 10 & 0,32 & 0,37 & 0,41 & 0,49 \\
\hline 15 & 0,27 & 0,30 & 0,34 & 0,40 \\
\hline 20 & 0,23 & 0,26 & 0,29 & 0,36 \\
\hline 25 & 0,21 & 0,24 & 0,27 & 0,32 \\
\hline 30 & 0,19 & 0,22 & 0,24 & 0,29 \\
\hline 35 & 0,18 & 0,20 & 0,23 & 0,27 \\
\hline 40 & 0,17 & 0,19 & 0,21 & 0,25 \\
\hline 45 & 0,16 & 0,18 & 0,20 & 0,24 \\
\hline 50 & 0,15 & 0,17 & 0,19 & 0,23 \\
\hline $\mathrm{n}>50$ & $1,07 / \mathrm{n}^{0,5}$ & $1,22 / \mathrm{n}^{0,5}$ & $1,36 / \mathrm{n}^{0,5}$ & $1,63 / \mathrm{n}^{0,5}$ \\
\hline
\end{tabular}

\section{Dependable Flow}

Dependable discharge can be calculated based on dependable rainfall (effective rainfall). Dependable flow is the minimum flow for probability of meeting with probability $80 \%$ [9]. Rainfall data are sorted from largest to smallest and then given a number as " $\mathrm{m}$ ". The probability is calculated by the formula $\mathrm{P}=\mathrm{m} /(1+\mathrm{n})$ where " $\mathrm{n}$ " is the number of data. Values have seen an $80 \%$ probability of the sequence number ' $m$ ". If the value is not exactly $80 \%$ probability is the number " $\mathrm{m}$ " then do interpolation to get an $80 \%$ probability.

\section{E. Water Availability}

Water availability determined based on rainfall data is then calculated as the rainfall intensity. The calculation of the rainfall intensity with Mononobe equation [10] as follows:

$$
I_{T}=\frac{R_{24 T}}{24}\left(\frac{24}{T_{c}}\right)^{2 / 3}
$$

Time-concentration (Tc) by Kirpich:

$$
T_{c}=0.00013 \frac{L^{0.77}}{S^{0.385}}
$$

Where "I" is rainfall intensity (mm/hours), " $R_{24}$ "is maximum rainfall in 24 hours $(\mathrm{mm})$ and "Tc" is the duration of rainfall.

Runoff coefficient is the ratio of the rainfall as runoff. The coefficient of runoff ranges from 0 to 1 and depending on the soil type, vegetation type, characteristics of land use and construction surfaces such as paved roads, roofs of buildings and others that cause rain could not directly onto the surface of the ground so it cannot infiltrate and will produce nearly $100 \%$ runoff [9]:

Runoff coefficient regions:

$$
C_{\text {Re gion }}=\frac{\left.\left(C_{i} * A_{i}\right)+\left(C_{i+1} * A_{i+1}\right)+\ldots \ldots+C_{i+n} * A_{i+n}\right)}{A_{\text {Re gion }}}
$$

The discharge calculated by rational methods:

$$
Q=0,278 . C . I . A
$$

Where "Q" is discharged $\left(\mathrm{m}^{3} / \mathrm{sec}\right)$, "C" is Runoff coefficient, "I" is rainfall intensity (mm/hours) and " $A$ " is Catchment area $\left(\mathrm{km}^{2}\right)$.

The land cover is considered to have a significant influence on the hydrological response of a watershed. The runoff coefficient of the peak current relationship varies from year to year with different land cover for each sub-catchment. The runoff coefficient increases with increasing forest proportions for peak specific peak conditions. The runoff coefficient associated with the occurrence of flood peaks decreases as agricultural and forest areas are disrupted. Forest areas tend to generate more runoff than non-forest areas [11]. Land use in the catchment area of Lake Toba is required to determine the runoff coefficient. Land use is shown in Table V. 
TABLE V. Land Use The Lake Toba

\begin{tabular}{|l|c|c|}
\hline \multicolumn{1}{|c|}{ Land } & Land Area (Ai) & \% \\
\hline Brushwood & 390.6 & 10.46 \\
\hline Lake & $1,126.97$ & 30.17 \\
\hline Forest & 765.06 & 20.48 \\
\hline Field & 266.89 & 7.15 \\
\hline Thicket fields & 477.84 & 12.79 \\
\hline Meadow & 137.42 & 3.68 \\
\hline Open land & 21.27 & 0.57 \\
\hline Housing residents & 31.64 & 0.85 \\
\hline Grass & 289.6 & 7.75 \\
\hline Grass grove & 39.26 & 1.05 \\
\hline Paddy Field & 188.03 & 5.03 \\
\hline River & 0.2 & 0.01 \\
\hline
\end{tabular}

Input discharge will be compared with the output discharge that would be a consideration in for research conclusions.

\section{RESULT AND DISCUSSION}

The term estimate is used to refer to both past, current, and future population and it may refer, in the case of future population, to a projection, forecast or prediction. The distinction between a forecast and a prediction is not always clear, but they are generally taken to mean the same thing. Most statistical agencies, including Statistics Canada, claim to produce projections. These are calculations of future population based on a starting population and a certain assumed future growth rate, or components of growth [12]. The forecasting of district residents in North Sumatera was determined based on the total number that exists with population growth with equation (1). The results of district water needs of each region and its development are shown in Table VI.

TABLE VI. The District Water Needs Forecasts and the Discharge of Each Region

\begin{tabular}{|c|c|c|c|c|c|c|}
\hline \multirow{2}{*}{ Region } & \multicolumn{2}{|c|}{ Population } & \multicolumn{2}{|c|}{ Water needs (liters/day) } & \multirow{2}{*}{$\begin{array}{c}\text { Development } \\
\text { Needs } \\
\text { (liters/day) }\end{array}$} & \multirow{2}{*}{$\begin{array}{c}\text { Discharge } \\
\text { Need } \\
\left(\mathrm{m}^{3} / \mathrm{sec}\right)\end{array}$} \\
\hline & 2015 & 2032 & 2015 & 2032 & & \\
\hline Medan & $2,210,624$ & $2,569,660$ & $530,549,760$ & $616,718,439$ & $86,168,679$ & 23.94 \\
\hline Tebing Tinggi & 156,815 & 195,290 & $23,522,250$ & $29,293,487$ & $5,771,237$ & 1.60 \\
\hline Pematang Siantar & 247,411 & 290,125 & $37,111,650$ & $43,518,765$ & $6,407,115$ & 1.78 \\
\hline Simalungun & 849,405 & 946,142 & $127,410,750$ & $141,921,318$ & $14,510,568$ & 4.03 \\
\hline Deli Serdang & $2,029,308$ & $2,963,672$ & $385,568,520$ & $563,097,600$ & $177,529,080$ & 49.31 \\
\hline Serdang Bedagai & 608,691 & 649,590 & $91,303,650$ & $97,438,507$ & $6,134,857$ & 1.70 \\
\hline Total & $6,102,254$ & $7,616,511$ & $1,195,468,595$ & $1,491,990,148$ & $296,521,536$ & 82.37 \\
\hline
\end{tabular}

Integrated Water Regional Management (IWRM) is a promising approach in ensuring sustainable use of water resource and aims at focusing on proper usage and development of water resources through efficient and environmentally sound manner which not only satisfy demands for water but also safeguard freshwater [13]. Integrated Water Regional Management (IWRM) was planned in two systems, namely system 1 (Medan-Deli Serdang) with discharge $73.25 \mathrm{~m}^{3} / \mathrm{second}$ and system 2 (Simalungun-Tebing Tinggi-Pematang Siantar-Serdang Bedagai) with discharge $9.12 \mathrm{~m}^{3} / \mathrm{second}$, as shown in Table VII.

TABLE VII. Water Development Needs System 1 and System 2

\begin{tabular}{|c|l|c|c|}
\hline \multirow{2}{*}{ System } & \multicolumn{1}{|c|}{ Region } & Discharge Need $\left(\mathbf{m}^{3} \mathbf{s e c}\right)$ & \multirow{2}{*}{ Total } \\
\hline \multirow{2}{*}{1} & Medan & 23.94 & \multirow{2}{*}{73.25} \\
\cline { 2 - 3 } & Deli Serdang & 49.31 & \\
\hline \multirow{3}{*}{2} & Tebing Tinggi & 1.60 & \multirow{2}{*}{9.12} \\
\cline { 2 - 3 } & Pematang Siantar & 1.78 & \\
\cline { 2 - 4 } & Simalungun & 4.03 & \\
\cline { 2 - 4 } & Serdang Bedagai & 1.70 & \\
\hline
\end{tabular}


Most studies of long-term variations of rainfall. In Sri Lanka have used monthly totals, an analysis is extended here to include analysis of daily rainfall data in order to see how seasonal rainfall totals are reflected in the frequency of daily totals. Use of daily data allows the number of times in a given period that totals exceed a given threshold to be determined. This can include numbers of rain days [14].

The daily average rainfall based on the use of rainfall station data used minimum data, the results as shown in Table VIII.

TABLE VIII. Rainfall Monthly Minimum

\begin{tabular}{|c|c|c|c|c|c|c|c|c|}
\hline Tahun & $\begin{array}{c}\text { Situng } \\
\text { galing }\end{array}$ & Sitinjo & $\begin{array}{c}\text { Tj. } \\
\text { Gorbus }\end{array}$ & Pangururan & $\begin{array}{c}\text { Dolok } \\
\text { Sang gul }\end{array}$ & Laguboti & $\begin{array}{c}\text { Lumban } \\
\text { Julu }\end{array}$ & Average \\
\hline 1993 & 37 & 89 & 26 & 42 & 10 & 52 & 100 & 50,86 \\
\hline 1994 & 25 & 14 & 10 & 23 & 6 & 19 & 13 & 15,71 \\
\hline 1995 & 125 & 44 & 23 & 61 & 21 & 63 & 74 & 58,71 \\
\hline 1996 & 42 & 67 & 9 & 32 & 22 & 42 & 72 & 40,86 \\
\hline 1997 & 49 & 45 & 10 & 82 & 38 & 38 & 61 & 46,14 \\
\hline 1998 & 35 & 37 & 26 & 36 & 16 & 53 & 36 & 34,14 \\
\hline 1999 & 40 & 21 & 39 & 0 & 56 & 28 & 17 & 28,71 \\
\hline 2000 & 25 & 72 & 65 & 7 & 46 & 15 & 29 & 37,00 \\
\hline 2001 & 33 & 0 & 55 & 23 & 26 & 24 & 81 & 34,57 \\
\hline 2002 & 37 & 27 & 15 & 27 & 195 & 43 & 156 & 71,43 \\
\hline 2003 & 53 & 33 & 21 & 110 & 155 & 115 & 30 & 73,86 \\
\hline 2004 & 8 & 30 & 19 & 6 & 125 & 97 & 49 & 47,71 \\
\hline 2005 & 56 & 49 & 5 & 66 & 42 & 37 & 117 & 53,14 \\
\hline 2006 & 28 & 47 & 52 & 6 & 78 & 65 & 19 & 42,14 \\
\hline 2007 & 121 & 99 & 74 & 83 & 202 & 83 & 202 & 123,43 \\
\hline
\end{tabular}

Before rainfall data were used, the consistency was tested. The method used in this test was the RAPS (Rescaled Adjusted Partial Sum) method. Measures consistency used rainfall station data then it was determined using equations (2) to (8). Analysis of minimum monthly rainfall consistency data Table 9 that a significant level (confidence level) of $90 \%$ indicates the critical value of $\mathrm{Q} / \mathrm{n}^{(0,5)}$ and $\mathrm{R} / \mathrm{n}^{(0,5)}$.

The data from all rain stations were smaller than the value (Table IX) so that the rainfall data were consistent and usable.

TABLE IX. Calculation Rainfall Consistency Data Test From All Stations

\begin{tabular}{|c|c|c|c|c|}
\hline Rainfall Data & $\mathbf{Q} / \mathbf{n}^{\mathbf{0 , 5}}$ & Results & $\mathbf{R} / \mathbf{n}^{\mathbf{0 , 5}}$ & Results \\
\hline Situnggaling & $0,475<1,075$ & Consistent & $0,467<1,275$ & Consistent \\
\hline Sitinjo & $0,332<1,075$ & Consistent & $0,332<1,275$ & Consistent \\
\hline Tj Gorbus & $0,271<1,075$ & Consistent & $0,246<1,275$ & Consistent \\
\hline Pangururan & $0,262<1,075$ & Consistent & $0,252<1,275$ & Consistent \\
\hline Dolok Sanggul & $0,815<1,075$ & Consistent & $0,761<1,275$ & Consistent \\
\hline Laguboti & $0,389<1,075$ & Consistent & $0,387<1,275$ & Consistent \\
\hline Lumban Julu & $0,808<1,075$ & Consistent & $0,798<1,275$ & Consistent \\
\hline
\end{tabular}

The Kolmogorov-Smirnov test is a nonparametric goodness-of-fit test and is used to determine whether two distributions differ, or whether an underlying probability distribution differs from a hypothesized distribution. It is used when we have two samples coming from two populations that can be different. The KolmogorovSmirnov test has the advantage of considering the distribution functions collectively. The Kolmogorov-Smirnov test can also be used as a goodness-of-fit test [15].

The distribution of Goodness fittest used Kolmogorov-Smirnov test, the distribution test results were shown in Table X. 
TABLE X. Calculate Smirnov-Kolmogorov Distribution Test

\begin{tabular}{|c|c|c|c|c|c|}
\hline $\mathbf{M}$ & Rainfall (R) & $\mathbf{P}=\mathbf{m} /(\mathbf{n}+\mathbf{1})$ & $\mathbf{T}$ & $\mathbf{P}^{\prime}=\mathbf{1} / \mathbf{T}$ & $\mathbf{D}=\left|\mathbf{P}^{\prime} \mathbf{P}^{\prime}\right|$ \\
\hline 1 & 123,43 & 0,06 & 27,673 & 0,036 & 0,026 \\
\hline 2 & 73,86 & 0,13 & 4,424 & 0,226 & 0,101 \\
\hline 3 & 71,43 & 0,19 & 4,072 & 0,246 & 0,058 \\
\hline 4 & 59,71 & 0,25 & 2,780 & 0,360 & 0,110 \\
\hline 5 & 53,14 & 0,31 & 2,282 & 0,438 & 0,126 \\
\hline 6 & 50,86 & 0,38 & 2,139 & 0,468 & 0,093 \\
\hline 7 & 47,71 & 0,44 & 1,961 & 0,510 & 0,072 \\
\hline 8 & 46,14 & 0,50 & 1,881 & 0,532 & 0,032 \\
\hline 9 & 42,14 & 0,56 & 1,701 & 0,588 & 0,026 \\
\hline 10 & 40,86 & 0,63 & 1,649 & 0,606 & 0,019 \\
\hline 11 & 37,00 & 0,69 & 1,511 & 0,662 & 0,026 \\
\hline 12 & 34,57 & 0,75 & 1,436 & 0,697 & 0,053 \\
\hline 13 & 34,14 & 0,81 & 1,423 & 0,703 & 0,110 \\
\hline 14 & 28,71 & 0,88 & 1,287 & 0,777 & 0,098 \\
\hline 15 & 15,71 & 0,94 & 1,090 & 0,918 & 0,020 \\
\hline
\end{tabular}

Table $\mathrm{X}$ presents that the value of $\mathrm{D}_{\max }$ " $\mathrm{m}$ " is line 5 (highlight) Dmax value is 0.126 . Table IV shows that $\mathrm{n}$ $=15$ with a confidence level $\alpha=5 \%$, the value obtained from $\mathrm{Do}=0.34$. Here it can be seen that "D $\mathrm{Dax}_{\max }<\mathrm{Do}^{\prime}$, then the distribution of data can be accepted.

The dependable discharge was determined based on reliable rainfall (effective rainfall). Dependable flow is the minimum flow for a probability of meeting with probability $80 \%$.

TABLE XI. Dependable Flow With a Probability $80 \%$

\begin{tabular}{|c|c|c|c|c|}
\hline Years & Rainfall & $\begin{array}{c}\text { Rainfall from largest to } \\
\text { smallest }\end{array}$ & Serial Number (m) & $\begin{array}{c}\text { Probability } \\
\mathbf{P}=\mathbf{m} /(\mathbf{n}+1)(\%)\end{array}$ \\
\hline 1993 & 50,86 & 123.43 & 1 & 6.25 \\
\hline 1994 & 15,71 & 73.86 & 2 & 12.5 \\
\hline 1995 & 58,71 & 71.43 & 3 & 18.75 \\
\hline 1996 & 40,86 & 58,71 & 4 & 25 \\
\hline 1997 & 46,14 & 53.14 & 5 & 31.25 \\
\hline 1998 & 34,14 & 50.86 & 6 & 37.5 \\
\hline 1999 & 28,71 & 47.71 & 7 & 43.75 \\
\hline 2000 & 37,00 & 46.14 & 8 & 50 \\
\hline 2001 & 34,57 & 42.14 & 9 & 56.25 \\
\hline 2002 & 71,43 & 40.86 & 10 & 62.5 \\
\hline 2003 & 73,86 & 37.00 & 11 & 68.75 \\
\hline 2004 & 47,71 & 34.57 & 12 & 75 \\
\hline 2005 & 53,14 & 34.14 & 13 & 81.25 \\
\hline 2006 & 42,14 & 28.71 & 14 & 87.5 \\
\hline 2007 & 123,43 & 15.71 & 15 & 93.75 \\
\hline
\end{tabular}

Rainfall data were sorted from the largest to the smallest and numbered as " $m$ ". The probability was given by the formula $\mathrm{P}=\mathrm{m} /(1+\mathrm{n})$ where " $\mathrm{n}$ " is the amount of data. The probability value of $80 \%$ was between "m" 12 and 13 (highlight). The probability of "m" 12 is $75 \%$ with rainfall of $34.57 \mathrm{~mm}$ and the probability of "m" 13 was $81.25 \%$ with rainfall of $34.14 \mathrm{~mm} .80 \%$ probability by interpolating rainfall result was $34,38 \mathrm{~mm}$.

Probability $80 \%$ of rainfall was used to determine $80 \%$ discharge as annual discharge. The intensity of rainfall was determined based on the probability of $80 \%$ rainfall $(0.997 \mathrm{~mm})$ in concentration time $(\mathrm{Tc}=1.482$ hours), rainfall intensity was $0.23 \mathrm{~mm} /$ hour.

Land use in Lake Toba is to determine the runoff coefficient. The area of Lake Toba is 3,374,79ha. Furthermore, the regional runoff coefficient was 0.51 as shown in Table XII. 
TABLE XII. Region Runoff Coefficient (C)

\begin{tabular}{|c|c|c|c|}
\hline Land & Land Area (Ai) Ha & Runoff Coefficient (Ci) & $\mathrm{C}_{\mathrm{i}}^{*} \mathrm{~A}_{\mathrm{i}}$ \\
\hline Brushwood & 390.60 & 0.55 & 214.83 \\
\hline Lake & $1,126.97$ & 0.90 & $1,014.27$ \\
\hline Forest & 765.06 & 0.20 & 153.01 \\
\hline Field & 266.89 & 0.40 & 106.76 \\
\hline Thicket fields & 477.84 & 0.50 & 238.92 \\
\hline Meadow & 137.42 & 0.30 & 41.23 \\
\hline Open land & 21.27 & 0.50 & 10.63 \\
\hline Housing residents & 31.64 & 0.55 & 17.40 \\
\hline Grass & 289.60 & 0.21 & 60.82 \\
\hline Grass grove & 39.26 & 0.40 & 15.70 \\
\hline Paddy Field & 188.03 & 0.15 & 28.20 \\
\hline River & 0.20062 & 0.60 & 0.12 \\
\hline Total & $3,734.79$ & & $1,901.90$ \\
\hline \multicolumn{2}{|c|}{ Region runoff coefficient $C$} & 0.51 & \\
\hline
\end{tabular}

Dependable discharge $80 \%$ is determined by the Mononobe rational method in equation (12) where the determination is based on the coefficient of runoff, rainfall intensity, and service area. The Dependable discharge $80 \%$ result is $121.79 \mathrm{~m}^{3} / \mathrm{sec}$.

In addition, the water source of Lake Toba also some waterfalls that enter the river that contributes as input various waterfalls and rivers contributing to Lake Toba as shown in Table XIII.

Table XIII. Source of Discharge Contribution from the Rivers

\begin{tabular}{|l|l|c|}
\hline \multicolumn{1}{|c|}{ Waterfall } & \multicolumn{1}{c|}{ Rivers } & $\begin{array}{c}\text { Average Discharge } \\
\left(\mathbf{m}^{\mathbf{3}} \mathbf{\text { det}}\right)\end{array}$ \\
\hline Sipulak & Aek Siharar & 5.00 \\
\hline Peadungdung & Aek Peadungdung & 2.00 \\
\hline Pollung & Aek Sibuluan & 4.00 \\
\hline Tahurjati & Sei Sopang & 2.00 \\
\hline Simandame & Aek Sisira & 6.00 \\
\hline Namo Sarangan & Aek Sisira & 3.00 \\
\hline Sibokkik & Aek Rambe & 4.00 \\
\hline Simursa & Sei Simursa & 2.00 \\
\hline Simursa II & Sei Simursa II & 1.50 \\
\hline Sibabo & Aek Simonggo & 10.00 \\
\hline Simolap & Sei Baringin & 3.00 \\
\hline Sipang & Aek Sipang & 0.80 \\
\hline Ompu Sarme & Aek Pungga & 2.00 \\
\hline Raja Panopa & Aek Pungga & 3.00 \\
\hline Ompu Lagang & Aek Mahumba & 3.00 \\
\hline Nadumonggor & Aek Sibuluan & 2.50 \\
\hline Sipultak Hoda & Aek Silintong Gota-gota & 2.00 \\
\hline Janji & Binanga Janji & 1.50 \\
\hline Manonga Tao & Aek Silang & 10.00 \\
\hline Parpahuan & Aek Silang & 10.00 \\
\hline Sibundong II & Aek Sibundong & 5.00 \\
\hline Sibundong III & Aek Sibundong & 5.00 \\
\hline & Total & 87.30 \\
\hline
\end{tabular}

The population in 2015 was 6,102,254 people, the largest in Medan was 2,210,624 people and the lowest was Tebing Tinggi with 156,815 people. By 2032, population forecasting in the service area is estimated to be $7,616,511$ people with the addition of $1,514,257$ people, so that the demand for raw water by population increases from $1,195,468,595$ liters/day (2015) to $1,491,990,144$ liters/day (2032) with increase of $24.80 \%$ 
The service area was divided into two systems, namely system 1 (Medan-Deli Serdang) and system 2 (Simalungun-Tebing Tinggi-Pematang Siantar-Bedagai Serdang). The raw water needs for both systems were $73.25 \mathrm{~m}^{3} / \mathrm{sec}$ (system 1 ) and $9.12 \mathrm{~m}^{3} / \mathrm{sec}$ (system 2). This illustrated that the system needs (Medan-Deli Serdang) were very high as shown in Table VII

According to consistency data test with Rescaled Adjusted Partial Sum (RAPS) method by a significant level (confidence level) 90\% indicates that the rainfall data is consistent and can be accepted as well as Goodness fittest by Kolmogorov Smirnov also acceptable therefore rainfall data can be used to calculate supply water.

Rain intensity probability $80 \%$ is $0.23 \mathrm{~mm}$ /hour, runoff coefficient region is 0.51 so that input discharge probability $80 \%$ within Rational Mononobe $121.79 \mathrm{~m} 3 / \mathrm{sec}$. Comparison of the water balance is a consideration in the conclusions.

The results suggest that the discharges required $82.37 \mathrm{~m}^{3} / \mathrm{sec}$ (output discharge) while the supply of rainfall $121.79 \mathrm{~m}^{3} / \mathrm{sec}$. In addition, the supply of the rivers around that contributed $87.3 \mathrm{~m}^{3} / \mathrm{sec}$ so that discharge input total $209.09 \mathrm{~m}^{3} / \mathrm{sec}$.

In plan of Integrated Water Regional Management (IWRM) North Sumatera, which will use Lake Toba as a water source, it is necessary to consider a decline normal water levels, therefore can be illustrated that the output discharge is smaller than the input discharge and it can be concluded that the water of Lake Toba can be used and not affecting the normal water level.

\section{CONCLUSION}

The results showed that required discharges was $82.37 \mathrm{~m}^{3} / \mathrm{sec}$ (output discharge), while the supply of rainfall was $121.79 \mathrm{~m}^{3} / \mathrm{sec}$. In addition, the supply of rivers around Lake Toba contributed $87.3 \mathrm{~m}^{3} / \mathrm{sec}$, resulting in total discharge to $209.09 \mathrm{~m}^{3} / \mathrm{sec}$ (input discharge), therefore can be illustrated that the output discharge is smaller than the input discharge and it can be concluded that the water of Lake Toba can be used and not affecting the normal water level. To safeguard forests as groundwater buffers, it is advisable to expand forest areas through reforestation and increase productive forest areas.

\section{ACKNOWLEDGMENT}

The authors would like to thank the North Sumatera Government for the financial research support and Universitas Malikussaleh for providing research facilities.

\section{REFERENCES}

[1] H. Aspan, F. Milanie, and M. Khaddafi, "SWOT Analysis of the Regional Development Strategy City Field Services for Clean Water Needsc," Int. J. Acad. Res. Bus. Soc. Sci., vol. 5, no. 12, 2016.

[2] M. C. Acreman, J. R. Meigh, and K. J. Sene, "Modelling the decline in water level of Lake Toba, Indonesia," Adv. Water Resour., vol. 16, no. 4, pp. 207-222, 1993

[3] BPS Provinsi Sumatera Utara, Provinsi iSumatera Utara Dalam Angka 2016. BPS Provinsi Sumatera Utara, 2016.

[4] P. McDonald, “A Population Projection for Indonesia, 2010-2035,” Bull. Indones. Econ. Stud., vol. 50, no. 1, pp. 123-129, 2014.

[5] Directorate General of Human Settlements, Technical Guidelines for the Division of Water. Jakarta: Ministry of Public Works, 2007.

[6] S. Sosrodarsono and K. Takeda, Hydrology for Irrigation. Jakarta: Pradnya Paramita PT, 1997.

[7] T. A. Buishand, "Some methods for testing the homogeneity of rainfall records," J. Hydrol., vol. 58, no. 1-2, pp. 11-27, 1982.

[8] F. J. Massey Jr, "The Kolmogorov-Smirnov test for goodness of fit," J. Am. Stat. Assoc., vol. 46, no. 253, pp. 68-78, 2005.

[9] V. T. Chow, D. Maidment, and L. Mays, Applied Of Hydrology. New York: McGraw Hill Book Company, 1988.

[10] W. Wesli, "Operation Planning Reservoir with Linear Programming Optimization Model for Water Demand of the Community In Aceh Besar District," Indones. J. Geogr., vol. 47, no. 1, p. 99, 2015.

[11] N. Sriwongsitanon and W. Taesombat, "Effects of land cover on runoff coefficient," J. Hydrol., vol. 410, no. 3-4, pp. 226-238, 2011.

[12] M. V. George, "Population forecasting in Canada: conceptual and methodological developments," Can. Stud. Popul., vol. 28, no. 1, p. $111,2001$.

[13] A. A. Ako, G. E. T. Eyong, and G. E. Nkeng, "Water Resources Management and Integrated Water Resources Management (IWRM) in Cameroon," Water Resour. Manag., vol. 24, no. 5, pp. 871-888, 2009.

[14] T. Burt and K. Weerasinghe, "Rainfall Distributions in Sri Lanka in Time and Space: An Analysis Based on Daily Rainfall Data," Climate, vol. 2, no. 4, pp. 242-263, 2014.

[15] F. Calitz, "An alternative to the kolmogorov-smirnov test for goodness of fit," Commun. Stat. - Theory Methods, vol. 16, no. 12, pp. 3519-3534, Jan. 1987.

\section{Author Profile}

Dr. Ir. Wesli, MT is a senior lecturer in Civil Engineering Department of Universitas Malikussaleh, Province Aceh, Indonesia. He has published various research papers in National and International. His areas of interests are drinking water, hydrology, Water Resources Management, Drainage, and Regional Planning. 